\title{
The Role of Fluorinated Polymers in the Water Management of Proton Exchange Membrane Fuel Cells: A Review
}

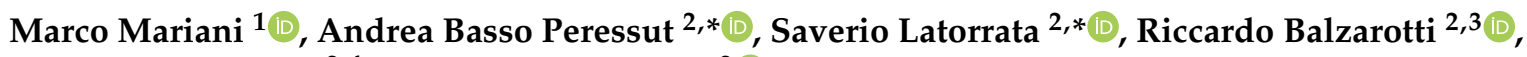 \\ Maurizio Sansotera ${ }^{2,4}$ and Giovanni Dotelli ${ }^{2}$ (D) \\ 1 Department of Mechanical Engineering, Politecnico di Milano, Via La Masa 1, 20156 Milano, Italy; \\ marco.mariani@polimi.it \\ 2 Department of Chemistry, Materials and Chemical Engineering "G. Natta", Politecnico di Milano, \\ Piazza Leonardo da Vinci 32, 20133 Milano, Italy; riccardo.balzarotti@polimi.it (R.B.); \\ maurizio.sansotera@polimi.it (M.S.); giovanni.dotelli@polimi.it (G.D.) \\ 3 Elettrotecnica ROLD S.R.L., Via della Merlata 1, 20014 Milano, Italy \\ 4 INSTM-Consorzio Interuniversitario Nazionale per la Scienza e Tecnologia dei Materiali (UdR-PoliMi), Via G \\ Giusti 9, 50121 Firenze, Italy \\ * Correspondence: andreastefano.basso@polimi.it (A.B.P.); saverio.latorrata@polimi.it (S.L.)
}

Citation: Mariani, M.; Basso

Peressut, A.; Latorrata, S.; Balzarotti,

R.; Sansotera, M.; Dotelli, G. The Role of Fluorinated Polymers in the Water Management of Proton Exchange Membrane Fuel Cells: A Review. Energies 2021, 14, 8387. https:// doi.org/10.3390/en14248387

Academic Editor: Attilio Converti

Received: 9 November 2021

Accepted: 10 December 2021

Published: 13 December 2021

Publisher's Note: MDPI stays neutral with regard to jurisdictional claims in published maps and institutional affiliations.

Copyright: (c) 2021 by the authors. Licensee MDPI, Basel, Switzerland. This article is an open access article distributed under the terms and conditions of the Creative Commons Attribution (CC BY) license (https:// creativecommons.org/licenses/by/ $4.0 /)$.

\begin{abstract}
As the hydrogen market is projected to grow in the next decades, the development of more efficient and better-performing polymer electrolyte membrane fuel cells (PEMFCs) is certainly needed. Water management is one of the main issues faced by these devices and is strictly related to the employment of fluorinated materials in the gas diffusion medium (GDM). Fluorine-based polymers are added as hydrophobic agents for gas diffusion layers (GDL) or in the ink composition of microporous layers (MPL), with the goal of reducing the risk of membrane dehydration and cell flooding. In this review, the state of the art of fluorinated polymers for fuel cells is presented. The most common ones are polytetrafluoroethylene (PTFE) and fluorinated ethylene propylene (FEP), however, other compounds such as PFA, PVDF, PFPE, and $\mathrm{CF}_{4}$ have been studied and reported. The effects of these materials on device performances are analyzed and described. Particular attention is dedicated to the influence of polymer content on the variation of the fuel cell component properties, namely conductivity, durability, hydrophobicity, and porosity, and on the PEMFC behavior at different current densities and under multiple operating conditions.
\end{abstract}

Keywords: fluorinated polymer; gas diffusion layer; microporous layer; PEM fuel cell; PTFE; FEP; PFA; PVDF; PFPE; $\mathrm{CF}_{4}$

\section{Introduction}

Fluorinated polymers are a category of materials that finds application in multiple industry sectors, such as energy, aerospace, construction, automotive, and petrochemical, thanks to their versatility. Indeed, these polymers display remarkable chemical inertness and resistance to acidic and basic attacks, due to the stability of the C-F bond (bond energy $=485 \mathrm{~kJ} \cdot \mathrm{mol}^{-1}$ ), high flame resistance, and limited oxidation [1]. In addition, they normally feature extended thermal and mechanical stability that prevents the quick arising of degradation mechanisms related to heat cycles [2]. These properties, combined with their low surface tension, make them suitable for the hydrophobization treatment of polymer electrolyte membrane fuel cells (PEMFCs) components [3].

PEMFC devices convert directly chemical energy into electricity by performing half redox reactions at their electrodes [4,5]. The electrodes are normally constituted by catalyst layers applied as coatings on the opposite sides of a polymeric ionomer membrane acting as the electrolyte [6]. The reactive gases are fed through two bipolar plates, which enclose the cell and act as current collectors.

One of the main components of a PEM fuel cell (see Figure 1) is called a gas diffusion 
layer (GDL), which can be coated with a carbon-based ink, thus producing a microporous layer (MPL) [7-11]. Together, they are referred to as the gas diffusion medium (GDM). It is inserted in-between the catalyst layer and the bipolar plate and is crucial for proper operation of the whole device. Indeed, although it does not directly take place in the electrochemical reactions, a GDM has to accomplish several fundamental targets: it has to allow a uniform diffusion of reactant gases from the bipolar plate channels to the catalyst layer and thus to the entire active area; it has to manage and to quickly remove generated water from the electrode towards the flow field channels. It also removes heat, which is generated in the electrochemical reaction, and electrically connects the electrode to the bipolar plate, hence to the external circuit. Finally, it must provide mechanical support to the membrane electrode assembly, avoiding its sagging into the flow field channels.

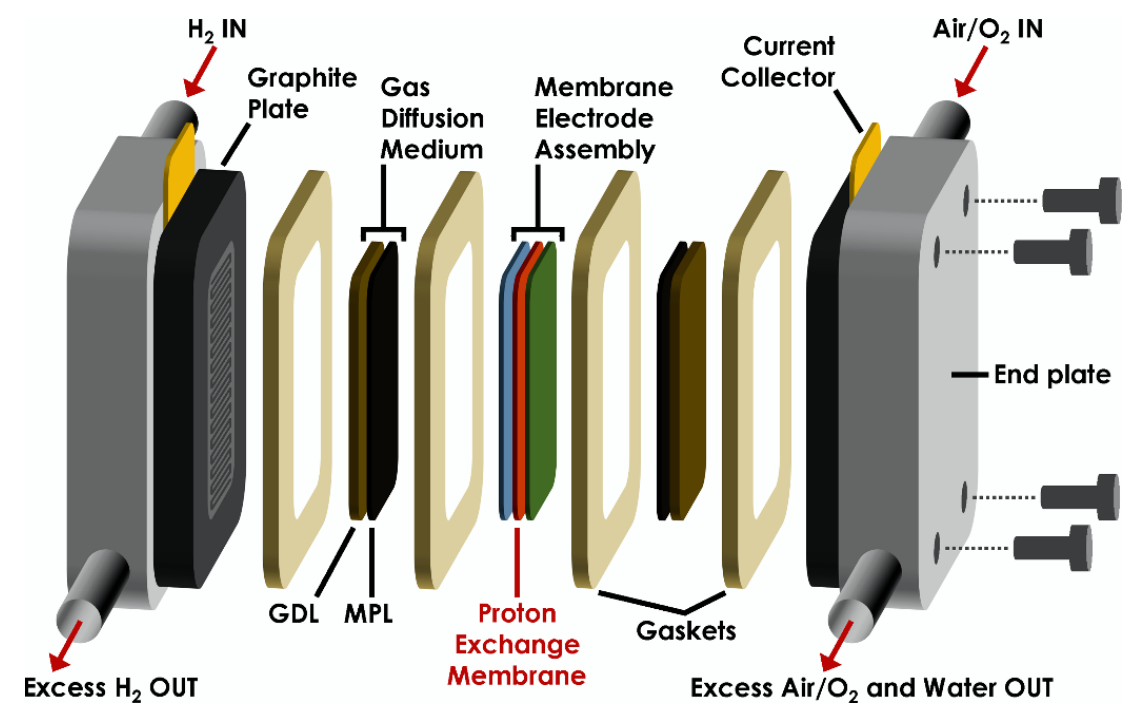

Figure 1. Structure of a polymer electrolyte membrane fuel cell (PEMFC).

A GDM must show specific properties to fulfil the requirements demanded by its functions: it must be sufficiently porous to allow the flow of reactants and water, which move in opposite directions. It must be electrically and thermally conductive, both in-plane and through-plane; a low contact resistance is usually more important than the bulk one in determining a low overall ohmic resistance. It must be sufficiently rigid to support the membrane and the electrode. Finally, a certain hydrophobicity is usually needed to effectively remove generated water.

The aforementioned properties are typically obtained by using carbon fiber-based materials; woven carbon cloths and carbon papers are the best materials for GDLs that meet such requirements, although other different materials have been successfully tested and reported in the literature $[9,12]$. Instead, MPLs are obtained from inks applied on top of the GDLs with different techniques such as doctor-blade coating, spin coating, spraying, and brushing. These inks are obtained by mixing a liquid medium (typically water) with various carbon-based materials (e.g., carbon black, carbon nanotubes, or graphene nanoparticles); typically, a dispersing agent (e.g., isopropyl alcohol) is added to improve the contact between the carbon materials and water, thus obtaining homogeneous and well-dispersed slurries. In some cases, a hydrophilizing agent (e.g., carboxy-methyl-cellulose) is further added to produce hybrid/mixed coatings and to act as a pore-forming agent [13-16].

Water flooding in porous components, such as gas diffusion media (GDMs), is a critical aspect that can affect the performance of the whole fuel cell [17-21]. Indeed, under severe operating conditions, i.e., high humidity levels or high current densities, a huge amount of water, if not properly discharged out of the cell, can block the pores of carbonaceous materials or channels, thus hindering the reactant gases in reaching the active area of the membrane electrode assembly (MEA) and causing a sudden cell voltage drop. However, it 
is fundamental to maintain a sufficient level of ionomer hydration at low-medium current density, since it affects its conductivity, thus, the performance of the whole cell. Due to the presence of these competitive mechanisms (see Figure 2), proper water management is needed, and this task is usually accomplished by making GDLs hydrophobic by using a fluorinated polymer.

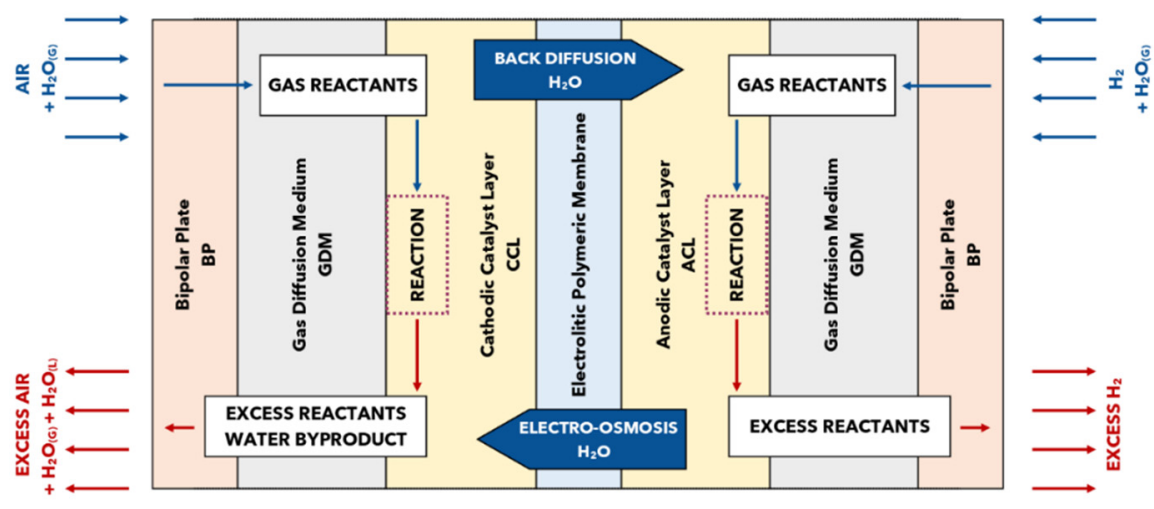

Figure 2. Schematic representation of a functioning PEM fuel cell with the gas and liquid flows.

Many reviews on different aspects of PEMFCs are reported in the literature, such as those describing gas diffusion media $[7,9,22,23]$, polymeric electrolytes, or other mechanisms [5,24-27]. Various attempts at modeling the aforementioned phenomena have been proposed to facilitate the analysis of the experimental results, predict outcomes in terms of power generation and water flooding, and design innovative components with specific flow patterns [28-31].

However, a comprehensive review on the employment of fluorinated materials is missing. Hereafter, we will describe the different types of polymers studied and used by the industry and face their effect on the most important features of gas diffusion layers: mass transport, electrical resistivity, thermal conductivity, and durability.

\section{Materials}

The use of fluorinated polymers within PEMFCs started during the 1990s and rapidly captured the interest of the scientific community, as shown by the quick growth in the number of published contributions in the early 2000s (Figure 3).

Use of fluorinated polymers in Gas Diffusion Media

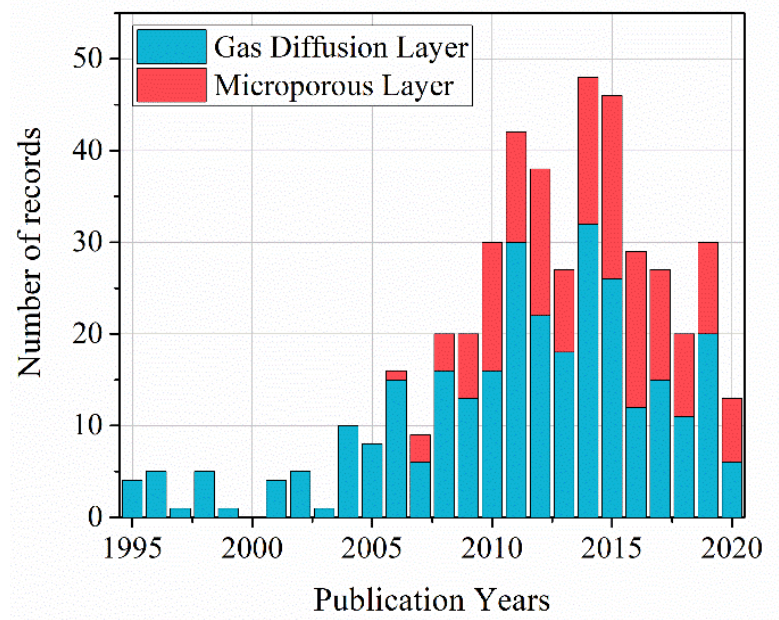

Figure 3. Track of records related specifically to the use of fluorinated polymers in gas diffusion media for PEMFCs. 
At first, GDLs themselves were not commonly employed in fuel cell stacks, therefore, fluorinated polymers were applied directly onto the MEA [32]. They were exploited as pore-formers to improve the infiltration of the inlet gases within the catalyst layer and as hydrophobizing agents to increase the water removal rate at high current densities. Later, gas diffusion layers (GDLs), microporous layers (MPLs), and gas diffusion electrodes (GDEs) were introduced in most stacks, thus adding a carbon paper or carbon cloth support to improve reactants' flow and distribution on the electrodes surface. It quickly became a common practice to also employ polytetrafluoroethylene (PTFE) in these components. Various studies soon demonstrated that the introduction of these hydrophobic polymers proved to be beneficial due to a reduction in the risk of cell flooding and to the tuning of the layer porosity; however, detrimental effects were observed too:

- $\quad$ the electrochemically active area was reduced (in the case of GDE) [33];

- $\quad$ the ohmic resistance of the carbon support was increased [33,34];

- $\quad$ the gas diffusion decreased at high PTFE loadings [34];

- the hydration rate of the ionomer-thanks to inlet gas humidity at low current densities-was limited [35].

Both Paganin et al. [35] and Giorgi et al. [36] demonstrated that the optimal amount of PTFE should be carefully weighted depending on the structure of the fuel cell stack and on the working current density. The former observed that the optimal ratio of PTFE/carbon loading to deposit on the carbon cloth was $15 \mathrm{wt} . \%$; the latter found the best ratio to be $10 \mathrm{wt} . \%$, with $20 \mathrm{wt} . \%$ being the loading at which the cell suffered the most from diffusion resistance at low current density. They showed that the polymer content should be minimal to positively affect the water removal efficiency from the cathodic site without reducing excessively the diffusion rate and the conductivity of the GDLs.

Later, different solutions and fluorinated polymers were investigated to maximize their beneficial effects. In particular, the materials employed so far, apart from PTFE, have been fluorinated ethylene propylene (FEP) [37,38], perfluoropolyether (PFPE) [39], polyvinylidene difluoride (PVDF) [40], perfluoroalcoxy alkanes (PFA) [41,42], and tetrafluoromethane $\left(\mathrm{CF}_{4}\right)$ plasma [43] (see Figure 4). Hereafter, we will analyze all of them, looking at the advantages provided and the issues still standing before their use.

(a)<smiles>CC(F)(C(F)(F)F)C(F)(F)C(F)(F)F</smiles>

(b)

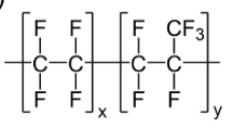

(c)

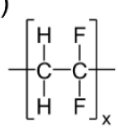

(d)

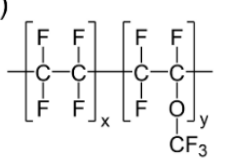

(e)

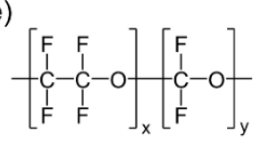

(f)<smiles>CCC(COC(=O)NCC1(C)CC(NC(=O)C(C)(C)C)CC(C)(C)C1)(COC(=O)NC1CCCC(C)(CNC(=O)OCC(C)(F)F)C1)C(=O)O</smiles>

Figure 4. Fluorinated polymers most widely used for the hydrophobization of gas diffusion media in PEMFCs: (a) PTFE; (b) FEP; (c) PVDF; (d) PFA; (e) a generic PFPE; (f) Fluorolink ${ }^{\circledR}$ P56 by Solvay, a commercial, high-molecular-weight, fluorinated polyurethane based on perfluoropolyether blocks; (g) $\mathrm{CF}_{4}$.

\subsection{PTFE}

PTFE and its derivatives are the most commercially available fluoropolymers accounting for more than $60 \%$ of the market share [44]. Their usually exploited properties are chemical inertness, thermal stability (decomposition by chain scission above $590{ }^{\circ} \mathrm{C}$ ), hydrophobicity, and low friction coefficient.

PTFE is usually dispersed in a stable aqueous suspension (5-45 wt.\% concentration) which can be applied to the GDL with different techniques, namely: dipping or floating of the carbon support in the suspension [34,45], brushing, spraying [36], vacuum-drying [33,35,46]. Different techniques have been introduced in specific cases, and the effect of homogeneous 
or nonhomogeneous polymer distributions in the GDL has been studied [47,48]. However, dipping has become the standard procedure due to its simplicity and possible scalability at the industrial level.

This step is then followed by thermal treatment aimed at inducing polymer sintering and evaporation of the solvent. The sintering temperature is usually about $350-360{ }^{\circ} \mathrm{C}[34-36,45,49]$. Indeed, PTFE has a first-order transition in-between 300 and $335{ }^{\circ} \mathrm{C}$ (depending on the initial degree of crystallinity), therefore, slightly higher temperatures are adopted to allow the formation of a melt-like phase and the coalescence of the polymer granules on the carbon fibers [50]. In particular, Bevers et al. [34] conducted a study on the effect of the sintering temperature of PTFE on the performance of the GDL, considering a range from 360 to $420^{\circ} \mathrm{C}$. They demonstrated that the increase in temperature did not affect the component hydrophobicity, however it allowed a larger flowing of the polymer from the carbon support pores to its fibers, thus coating their surface almost completely. This change reduced the resistance to gas flowing through the component; however, it increased the through-plane electrical resistance of the carbon paper. Finally, even though PTFE features alone do not favor them, lower sintering temperatures are usually employed because they minimize the risk of thermal degradation and weakening of the carbon fibers that are later subjected to strong compression during fuel cell mounting and functioning [23].

\subsubsection{Mass Transport}

The effect of PTFE addition on mass transport mechanisms inside the PEMFC is the result of multiple contributions. First, the filling of the carbon backing pores by the polymer must be considered. As already noted, larger amounts of PTFE drastically reduce the porosity of the GDL, thus hindering the flow of both gas reactants and water. Secondly, the hydrophobic property of the surfaces coated by the polymer changes the behavior of water inside this component: the repulsive effect on water prevents clogging of the carbon support, which reduces the risk of cell flooding at the cathodic side at high current density. Lastly, the introduction of PTFE could change the pore size distribution inside the GDL. This is critical for those coated by an MPL, whose aim is that of introducing a specific porosity gradient that exploits capillary pressure to improve water removal.

Bevers et al. [34] observed that large PTFE loads inside the GDL have a detrimental effect on the flow of gas because the polymer may create continuous films in-between the carbon fibers. In addition, this problem seems to be worsened by compression of the GDL inside the cell. Indeed, this induces compaction of polymer fragments, thus forming bigger agglomerates that can clog the carbon support pores. Park et al. [45] confirmed these conclusions with measurements of the mean pore diameter and the air permeability of differently treated carbon papers: an increase from $5 \mathrm{wt} \%$ to $45 \mathrm{wt}$. $\%$ of PTFE induced a $31 \%$ reduction of the mean pore diameter and a $25 \%$ increase of the air breakthrough pressure, i.e., the minimum pressure required to remove water from the component pores. These variations were reflected in the measured I-V curves. Indeed, although a small amount of PTFE helped stabilize the performances at high relative humidity of the inlet air with respect to untreated samples, the excessive increase of polymer content accelerated the cell flooding under all humidity conditions. Dai et al. [51] confirmed the reduction of liquid and vapor transport through the GDL at larger PTFE content. However, they also noted that this behavior could be beneficial to the cell performance under low RH conditions because it prevents the quick drying of the ionomer, whose conductivity is hydration-dependent. The detrimental effect of pore blocking by PTFE on gas diffusion have also been confirmed by measurements of the effective diffusion coefficients, which also noted a sharp increase in GDL tortuosity when polymer loading is raised from $20 \mathrm{wt} . \%$ to 40 wt.\% [52-55]. Biesdorf et al. [56,57] analyzed the effect of PTFE content on mass transport losses by combining I-V curves, constant current operations $\left(1 \mathrm{~A} \mathrm{~cm}^{-2}\right)$, pulsed gas analysis (PGA), and neutron radiography (NR). The first two techniques revealed that minimization of mass transport losses was achieved with a $5 \mathrm{wt}$ \% loading on the cathodic side, independently from the anodic side treatment, with negligible effect on the ohmic 
losses. PGA allowed to determine where mass losses were concentrated, and the analysis revealed that most of them are related to the GDL region ("bulk" losses) and not to the CL ("non-bulk" losses). Finally, NR revealed that the PTFE loading did not change the overall amount of water in the GDL at high current density, rather its distribution in the layer and its morphology. Indeed, it was observed that the uncoated GDL featured a larger accumulation of water below the flow channels rather than the plate ribs, thus increasing the mass transport resistance. Similar resistances were measured for highly coated carbon papers (20 wt.\%) but for a different reason: completely coated fibers favor the formation of water droplets which fill the pores and increase air path tortuosity, while partially coated fibers ( $5 \mathrm{wt} . \%$ ) induce the formation of water films on the fibers themselves, leaving the pores mostly unclogged.

The hydrophobic character of the GDL external and internal surfaces is of great importance because it affects the water adhesion and expulsion rate, therefore, the mass transport resistance of this component. Usually, this property is determined by the measurement of the static contact angle via the sessile drop technique. It has been observed that, on average, the measured contact angle is $135^{\circ}$ (see Figure 5): values go from a minimum of $105^{\circ}$ to a maximum of $152^{\circ}$ with PTFE loadings in the range of 5-60 wt.\% [45-47,49,52,58-63]. It must be noted that the correlation between polymer loading and the contact angle is not linear, since the hydrophobicity of the GDL surface depends also on other factors, such as manufacturing technique, surface roughness, and type of carbon support. Mortazavi et al. [49] studied in detail the behavior of water in contact with differently treated GDLs. They observed that surface hydrophobicity increases noticeably even with a small amount of PTFE (10 wt.\%), going from $129.7^{\circ}$ to $153.7^{\circ}$, but it does not raise further with larger loadings. However, they noted that larger polymer contents affect the droplet detachment diameter. This should be due to the infiltration of excess PTFE inside the GDL, which reduces the internal porosity and increases the inner carbon fibers' hydrophobicity, thus having a net effect of raising the internal capillary pressure [64]. Consequently, lower amounts of water infiltrate once inside the GDL, forming smaller droplets on the opposite side which detach more easily. Once again, the trade-off between the speed of droplet detachment and the amount of water throughput must be considered to determine the optimal polymer loading.

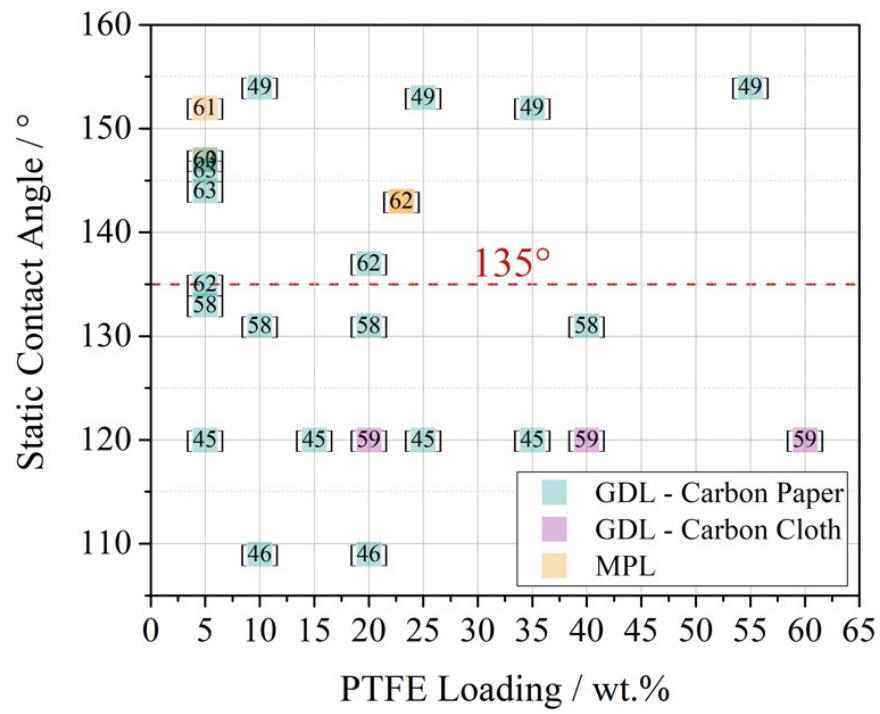

$[45]$ Park et al., 2004
$[46]$ Niu et al., 2018
$[49]$ Mortazavi et al., 2013
$[58]$ Fairweather et al., 2009
$[59]$ Benziger et al., 2005
$[60]$ Kandlikar et al., 2011
$[61]$ Ha et al., 2011
$[62]$ Burheim et al., 2013
$[63]$ Yang et al., 2018

Figure 5. Static contact angle values measured for GDLs with different PTFE loadings [45,46,49,58-63].

\subsubsection{Electrical Conductivity}

In-plane and through-plane electrical conductivities of the GDMs are of great importance because they affect the overall ohmic resistance of the fuel cell, thus impacting the efficiency of the device. While transverse conductivity directly affects the actual ohmic 
resistance of the stack, planar conductivity is not immediately related to this property. However, the importance of a low in-plane resistance is twofold:

- it allows an efficient charge transfer from the GDM to the whole surface of the catalyst layer, thus increasing the number of active sites for reaction.

- it accelerates the collection of electrons at the BP-GDM interface because it promotes the movement of charges from the region below the flow channels to the plates' ribs.

In addition, the surface morphology of the GDM must be carefully designed to minimize the contact resistance in the stack at the interfaces between the different layers. This contribution is often much greater than the bulk resistance of the components themselves and is only partially limited by the compression during cell assembling. Usually, troughplane and contact resistances are measured together, as the contribution of the former is negligible compared to that of the latter.

Ismail et al. $[65,66]$ considered both of these factors in their studies. First, they observed that a $30 \mathrm{wt}$ \% increase of PTFE loading in bare GDLs did not correspond to a significant variation of in-plane conductivity, likely due to the fact that the polymer coating did not induce ruptures or fractures in the carbon fibers. Similarly, the raise of PTFE content in MPLs was not detrimental, leading to the conclusion that, for this component, the nature and amount of the carbon particles is more influential than the polymer loading. On the contrary, the presence of the insulating constituent is relevant when considering the through-plane and contact resistances. While the electrons can find an uninterrupted path along an individual fiber in the in-plane direction, this is rather rare in the perpendicular direction, and a discontinuity is always present at the interface between components. Therefore, the presence of an insulating coating along the electron path affects the resistance. They measured a resistance decrease from $\sim 40$ to $\sim 20 \mathrm{~m} \Omega \mathrm{cm}^{2}$ with PTFE loadings at $30 \mathrm{wt} . \%$ and absence of polymer ( $0 \mathrm{wt} . \%)$, respectively. In addition, they described the resistance decay due to clamping pressure with the empirical power law:

$$
\mathrm{R}=\mathrm{AP}^{\wedge}(-\mathrm{B})
$$

where $R$ is the contact resistance, $P$ is the clamping pressure, and A and B are two coefficients that vary from $\left(\mathrm{A}=182.03 \Omega \mathrm{cm}^{2} \text { bar; } \mathrm{B}=1.194\right)_{0 \mathrm{wt} . \%}$ to $\left(\mathrm{A}=228.51 \Omega \mathrm{cm}^{2}\right.$ bar; $\mathrm{B}=0.987)_{30 \mathrm{wt} . \%}$.

El-Kharouf et al. [67] and Sadeghifar et al. [68] tested a long series of commercial GDMs and came to similar conclusions: the in-plane resistivity seems independent of the PTFE loading, which is detrimental to through-plane conductivity and contact resistance. However, it must be noticed that other factors, such as clamping pressure, MPL presence, humidity level, carbon support type, and thickness, seem to be more influential on the GDM electrical performance than polymer loading. Recently, improvements in the electrical conductivity have been demonstrated by adding TiN nanoparticles to the PTFE suspension prior to hydrophobization, allowing the achievement of similar results to that of untreated carbon papers [69].

\subsubsection{Thermal Conductivity}

Homogeneous heating inside the fuel cell is of great importance because it minimizes the risk of thermal stresses, which could reduce the durability of the components, and allows a better control on thermal profiles that determine the kinetics of reactions, species diffusivity, water evaporation, and electrical resistivity [70]. Similarly to what has been written for electrical conductivity, the addition of a weak thermally conductive polymer $\left(\mathrm{k}_{\mathrm{PTFE}}=0.35 \mathrm{~W} \mathrm{~m}^{-1} \mathrm{~K}^{-1}[71]\right)$ should be detrimental to the performance of the carbon support of GDMs; however, other factors, such as clamping pressure, compressive cycles, operating temperature, MPL presence, and inlet gases' relative humidity must be also considered when designing a cell stack [72-75].

Khandelwal et al. [76] were among the first to study this aspect of PEM fuel cells. They observed that an increase of PTFE content reduced GDL thermal conductivity (at 
$2 \mathrm{MPa}$ compression and $56-58^{\circ} \mathrm{C}$ ), from $0.48 \pm 0.09 \mathrm{~W} \mathrm{~m}^{-1} \mathrm{~K}^{-1}$ for untreated carbon paper to $0.31 \pm 0.06 \mathrm{~W} \mathrm{~m}^{-1} \mathrm{~K}^{-1}$ and $0.22 \pm 0.04 \mathrm{~W} \mathrm{~m}^{-1} \mathrm{~K}^{-1}$ for $5 \mathrm{wt} . \%$ and $20 \mathrm{wt} . \%$ PTFE loading, respectively. The contact resistance, instead, did not suffer from polymer addition (1.3/1.5/1.2 $\times 10^{-4} \mathrm{~K} \mathrm{~W}^{-1}$ for $0 / 5 / 20 \mathrm{wt}$.\% PTFE). Zamel et al. [77,78] measured both through-plane and in-plane thermal conductivities. They confirmed that the addition of polymer increases the thermal resistance in both directions. However, they observed that the difference between untreated and treated carbon papers is minimal under high compression $\left(16 \%\right.$ reduction in thickness) and for temperatures above $35^{\circ} \mathrm{C}$, likely due to an increase of the carbon fibers' contact points that preserves the conductivity regardless of the polymer coating. Accordingly, Sadeghi et al. [79] observed that the in-plane conductivity at $65-70{ }^{\circ} \mathrm{C}$ did not vary from 5 to $30 \mathrm{wt} . \%$ PTFE content and remained close to $17.5 \mathrm{~W} \mathrm{~m}^{-1} \mathrm{~K}^{-1}$. Alhazmi et al. [80,81] achieved similar results and noted that the independency of in-plane resistivity on PTFE content could actually be due to the fact that the polymer partially fills the porosity of the carbon support, thus removing air that is a greater insulator and compensating for its own poor conductivity. All the studies mentioned above agree that in-plane thermal conductivity (Table 1 ) is much greater than the through-plane one (Table 2), likely due to the anisotropic fiber distribution: in the first case, heat moves along the fibers without interruption; in the second case, it is transferred from one fiber to the next one, even though both are coated by PTFE that acts as a thermal barrier and reduces transfer efficiency.

Table 1. In-plane thermal conductivity values measured for GDLs with varying PTFE content.

\begin{tabular}{|c|c|c|c|c|}
\hline Material & $\begin{array}{l}\text { PTFE Loading } \\
\text { wt. } \%\end{array}$ & $\begin{array}{c}\text { Temperature } \\
{ }^{\circ} \mathrm{C}\end{array}$ & $\begin{array}{c}\text { In-Plane Thermal } \\
\text { Conductivity } \\
W \mathrm{~m}^{-1} \mathrm{~K}^{-1}\end{array}$ & Ref. \\
\hline \multirow{4}{*}{ Carbon Paper } & 5 & $65-70$ & 17.39 & \multirow{4}{*}{ [79] } \\
\hline & 10 & $65-70$ & 17.33 & \\
\hline & 20 & $65-70$ & 17.58 & \\
\hline & 30 & $65-70$ & 17.81 & \\
\hline \multirow{4}{*}{ Carbon Paper } & 0 & 70 & $12.5 \pm 0.9$ & \multirow{4}{*}{ [78] } \\
\hline & 5 & 70 & $10.6 \pm 0.7$ & \\
\hline & 20 & 70 & $\sim 11.0$ & \\
\hline & 50 & 70 & $\sim 11.7$ & \\
\hline \multirow{5}{*}{ Carbon Paper } & 0 & 110 & 13.3 & \multirow{5}{*}{ [82] } \\
\hline & 6 & 110 & 12.0 & \\
\hline & 11 & 110 & 9.73 & \\
\hline & 19 & 110 & 10.5 & \\
\hline & 30 & 110 & 15.1 & \\
\hline \multirow{5}{*}{ Carbon Paper } & 0 & 65 & 11.8 & \multirow{5}{*}{ [80] } \\
\hline & 5 & 65 & 11.6 & \\
\hline & 10 & 65 & 12.9 & \\
\hline & 20 & 65 & 14.1 & \\
\hline & 30 & 65 & 14.8 & \\
\hline
\end{tabular}

Table 2. Through-plane thermal conductivity values measured for GDLs with varying PTFE content.

\begin{tabular}{cccccc}
\hline Material & $\begin{array}{c}\text { PTFE Loading } \\
\text { wt. } \%\end{array}$ & $\begin{array}{c}\text { Compression } \\
\text { MPa }\end{array}$ & $\begin{array}{c}\text { Temperature } \\
{ }^{\circ} \mathbf{C}\end{array}$ & $\begin{array}{c}\text { Through-Plane Thermal } \\
\text { Conductivity } \\
\text { W } \mathbf{~ m}^{-\mathbf{1}} \mathbf{K}^{-\mathbf{1}}\end{array}$ & Ref. \\
\hline \multirow{3}{*}{ Carbon Paper } & 0 & 2 & 56 & $0.48 \pm 0.09$ & \\
& 5 & 2 & 58 & $0.31 \pm 0.06$ & {$[76]$} \\
\hline
\end{tabular}


Table 2. Cont.

\begin{tabular}{|c|c|c|c|c|c|}
\hline Material & $\begin{array}{l}\text { PTFE Loading } \\
\text { wt. } \%\end{array}$ & $\begin{array}{c}\text { Compression } \\
\mathrm{MPa}\end{array}$ & $\begin{array}{c}\text { Temperature } \\
{ }^{\circ} \mathrm{C}\end{array}$ & $\begin{array}{l}\text { Through-Plane Thermal } \\
\text { Conductivity } \\
\mathrm{W} \mathrm{m}^{-1} \mathrm{~K}^{-1}\end{array}$ & Ref. \\
\hline Carbon Paper & 5 & $\mathrm{~ns}^{1}$ & 20 & 1.008 & [83] \\
\hline \multirow{3}{*}{ Carbon Paper } & 12 & 1.38 & 70 & 0.55 & \multirow{3}{*}{ [84] } \\
\hline & 19 & 1.38 & 70 & 0.56 & \\
\hline & 29 & 1.38 & 70 & 0.62 & \\
\hline Carbon Paper & 5 & 0.5 & ns & 1.6 & [72] \\
\hline Carbon Paper & 30 & 2 & ns & 1.4 & [85] \\
\hline \multirow{2}{*}{ Carbon Paper } & 0 & 1.6 & 50 & 1.6 & \multirow{2}{*}{ [77] } \\
\hline & 60 & 1.6 & 50 & 1.3 & \\
\hline \multirow{3}{*}{ Carbon Paper } & 0 & 1.4 & 60 & 0.58 & \multirow{3}{*}{ [73] } \\
\hline & 5 & 1.4 & 60 & 0.55 & \\
\hline & 20 & 1.4 & 60 & 0.50 & \\
\hline \multirow{5}{*}{ Carbon Paper } & 0 & 2 & 35 & 0.55 & \multirow{5}{*}{ [81] } \\
\hline & 5 & 2 & 35 & 0.34 & \\
\hline & 10 & 2 & 35 & 0.29 & \\
\hline & 20 & 2 & 35 & 0.32 & \\
\hline & 30 & 2 & 35 & 0.33 & \\
\hline
\end{tabular}

${ }^{1}$ ns $=$ not specified

\subsubsection{Durability}

Lifetime duration of PEM fuel cells has been one of the major issues preventing their wide employment in automotive and industrial sectors. Dealing with the gradual degradation of the diverse components is a pending challenge, and GDMs face many troubles, such as mechanical degradation due to air/liquid flows and clamping pressure, chemical and electrochemical corrosion, and thermal stresses $[23,86]$. Polymer and carbon fibers have been optimized to enhance their resistance under severe operating conditions.

Ha et al. [61,87] were among the first to evaluate the effect of the acidic cathodic environment on the GDM. Through accelerated stress tests in a sulfuric acid solution at $80^{\circ} \mathrm{C}$, they demonstrated that hydrophobicity losses, thus performance, were due not to PTFE dissolution, but to degradation of either carbon resin or fibers and oxidation. SEM analyses confirmed the preservation of polymer coating during testing, while TGA underlined that mass losses due to temperature were not recorded below $150{ }^{\circ} \mathrm{C}$. Moreover, they demonstrated that higher polymer loadings are beneficial to the component as PTFE protects graphitized and carbonized resins from exposure to the acidic environment. Similar observations have been made on the results of ex situ stress tests for electrochemical degradation that occurs at high electric potential, such as during start-stop operations [88]. Once again, carbon materials seem to be more prone to degradation than fluorinated polymers. Material losses of fluorine-containing polymers are limited, and XPS analysis reveals only the conversion of $\mathrm{CF}_{2}$ groups to $\left[\mathrm{CF}_{\mathrm{x}}-\mathrm{CH}_{\mathrm{y}}\right]$ to a low extent $[89,90]$. Recently, Zhou et al. [69,91] assessed the impact of PTFE mixed with TiN nanoparticles on the corrosion resistance of carbon papers. They measured a decrease of both corrosion potential and current density as the polymer content was raised, with optimal results for a $15 \mathrm{wt} . \%$ PTFE/8 wt.\% TiN suspension. They confirmed that the hydrophobic coating acts as a barrier between the carbon substrate and the electrolyte, hindering the electron loss of carbon corrosion even at high voltage operations.

The structural integrity of the GDMs is strictly related to all kinds of mechanical stresses: compression during cell assembling, erosion and cavitation generated by fluids, strain cycles due to freezing conditions, membrane swelling, and thermal expansion. A careful evaluation of the possible solution to these degradation mechanisms starts with the assessment of the mechanical properties of the gas diffusion layers themselves. However, their fibrous structure makes any evaluation difficult to be made and generalized to different products that differ in texture, thickness, fiber radius, coatings, and thermal treatments. 
Poornesh et al. [92] measured the mechanical features of PTFE-coated single carbon fibers via nanoindentation, thus obtaining a maximum modulus of $3.5 \mathrm{GPa}$, declining to 1 GPa close to the fiber core, and an average fracture toughness of $250 \mathrm{MPa}$. Instead, when considering the whole GDL, the simplest method for evaluating its mechanical stability is assessing its features after multiple compression cycles [93]. It was immediately observed that this kind of solicitation induced damages to the component as breakage of the carbon fibers, crack formation, and PTFE loss, thus decreasing the hydrophobicity, lowering the breakthrough pressure, and increasing the water uptake [60]. It was noted that the addition of PTFE has a beneficial effect on the carbon support $[88,94]$. Increasing its content raises the stiffness of the carbon layer, as the polymer partially fills the pores and acts as a binder between the single fibers, stabilizing it even after multiple compression cycles. Ismail et al. [95] measured an increase of the compressive Young's modulus of 26.9-36.8\% when the PTFE content is raised from 5 to $30 \mathrm{wt} . \%$ in the GDL. Kumar et al. [88] observed that it is also important to consider the polymer distribution along the GDL thickness, as a larger surface loading helps preserving the component hydrophobicity under sever conditions.

In conclusion, PTFE is certainly beneficial to the GDL in terms of durability and performance stability. It acts as a barrier on the carbon fibers, reducing electrochemical corrosion and chemical degradation thanks to its inertness in an aggressive environment. In addition, it provides robustness to the carbon textile by creating an additional network between fibers, thus preventing the formation and propagation of cracks and damages.

\subsection{FEP}

Fluorinated ethylene propylene (FEP) is a viable alternative to PTFE, given the larger number of F-atoms per monomeric unit (see Figure 4) and the similar mechanical and electrical properties. One of the first use of this polymer in the field of gas diffusion components dates to Hočevar et al. [37], who employed PTFE in the catalyst layer and FEP in the diffusion layer. They evaluated by the ANOVA approach and numerical optimization procedure the optimal amounts of FEP content to be $16 \mathrm{wt} . \%$ at the cathodic side and $30 \mathrm{wt} . \%$ at the anodic side, in dependence of the specific PTFE content at the catalyst layer and of electrolyte thickness. As observed for PTFE, in the case of FEP as well, an optimum must be achieved to not reduce porosity, thus diffusivity, excessively while increasing the hydrophobicity of the component: at the cathode side, the amount of water is larger, and the reagent diffusivity is more limited in comparison to those at the anode side; thus, polymer addition should be lower than that at the anode, where the opposite is true. In 2004, Lim et al. [96] already observed that varying the polymer content in carbon paper from 10 to $40 \mathrm{wt} . \%$ produces only a small decrease of wettability (with absent variation at $80^{\circ} \mathrm{C}$ ), although it significantly raised the mass transfer resistance at high current density. Once again, this is due to pores clogging by the polymer that hinders the transfer of both oxygen and water. These results were also similarly demonstrated in other studies, and contents between 5 and $10 \mathrm{wt} . \%$ proved to be beneficial under most of the fuel cell working conditions [97-99].

The first comparative study between FEP and PTFE was presented by Park et al. [100], who analyzed the effects of the two polymers as coating agents on GDLs and as constituents of the inks used for MPLs. They proved the FEP-treated components to be superior to the PTFE counterpart because of a series of factors:

- the lower sintering temperature $\left(270{ }^{\circ} \mathrm{C}\right.$ vs. $\left.350-360{ }^{\circ} \mathrm{C}\right)$ that reduces the risk of thermal degradation of the carbon support;

- the less abrupt viscosity change of the slurry during sintering at lower temperature that allows the formation of smoother surfaces, which reduces the contact resistances;

- the superior compressive strength, which allows a higher joining pressure during cell assembly, thus lower contact resistances.

These features, combined with at least equal measured hydrophobicity [101], similar average pore size, and water-uptake, guarantee improved performances both at medium 
and high current density. In addition, FEP behaves as PTFE on electrical and thermal conductivity, therefore, the employment of the former polymer is not detrimental [102].

Finally, the improved surface adhesion and smoothness proved to be beneficial also to the components' durability. The increase of FEP content in the gas diffusion medium reduces both chemical and mechanical degradation (see Table 3), as proved by Latorrata et al. $[103,104]$, and stabilizes the electrical performances over time. This is of great importance in terms of fuel cell reliability and maintenance operations.

Table 3. Efficiency values calculated from polarization curves of fuel cells assembled with GDMs with increasing FEP content ( 3 to $12 \mathrm{wt} . \%$ ) tested as fresh components ( $0 \mathrm{~h}$ ), after constant current durability experiments ( $1000 \mathrm{~h}$ c.c.), and $1000 \mathrm{~h}$ of chemical $\left(\mathrm{AST}_{\mathrm{c}}\right)$ and mechanical $\left(\mathrm{AST}_{\mathrm{m}}\right)$ accelerated stress tests. Operating conditions: $60^{\circ} \mathrm{C}$ and RH 80-100\% (A-C). Data from [104].

\begin{tabular}{|c|c|c|c|c|}
\hline \multirow{2}{*}{ GDM } & \multicolumn{4}{|c|}{ Global Cell Efficiency \% } \\
\hline & $\mathbf{O h}$ & 1000 h c.c. & $1000 \mathrm{~h} \mathrm{AST}_{\mathrm{c}}$ & $1000 \mathrm{~h} \mathrm{AST}_{\mathrm{m}}$ \\
\hline FEP-3 & 41.30 & 38.00 & 37.23 & 27.27 \\
\hline FEP-6 & 42.51 & 39.50 & 38.08 & 29.33 \\
\hline FEP-9 & 42.51 & 42.00 & 41.66 & 35.59 \\
\hline FEP-12 & 43.72 & 43.70 & 42.94 & 41.66 \\
\hline
\end{tabular}

\subsection{Other Fluorinated Materials}

PTFE and FEP have been widely employed in the fabrication of GDMs; however, other fluorinated materials have been proposed over time as valid alternatives.

In 2006, Pai et al. proposed a $\mathrm{CF}_{4}$ plasma treatment on GDLs, which produced components that perform better than conventionally PTFE-treated materials, due to improved adhesion of the coating to the fibers and to a lower clogging of the carbon cloth porosity [43]. A more recent study by Chevalier et al. [105] confirmed that direct fluorination of diffusion supports by plasma treatment improved mass transfer in comparison to that of commercial PTFE-treated GDLs. Despite these positive results, the complexity of the apparatus required by this coating technique hindered its use, in favor of simpler and cost-effective procedures, such as dipping and spraying.

Polyvinylidene fluoride is another material that has been evaluated as a hydrophobic agent for GDMs. Ong et al. [40,106] for MPLs and Li et al. [107] for GDLs were the first to analyze the effect of this polymer on the respective components' behavior. Both studies evidenced that the main difference with conventional PTFE-treated layers consists in the abundance of cavities and porosities in PVDF-based samples, which enhances water and reactant diffusion under high current density. Therefore, both authors detected higher peak power densities for single fuel cell testing. In addition, PVDF has proved to be an excellent material for gas diffusion electrodes (GDEs) for high-temperature fuel cells (HT-PEMFC) [108-111]. Indeed, it tends to form fewer aggregates on the CL surface than PTFE while maintaining similar porosity, thus improving ohmic contact with the electrolyte. In addition, PVDF has lower charge transfer resistance, which improves the catalysts performance, and longer component stability (as verified by durability tests at $0.6 \mathrm{~V}$ and $\left.160{ }^{\circ} \mathrm{C}\right)$ [109].

Finally, a few other materials have been tested, specifically perfluoroalcoxy (PFA) and perfluoropolyether (PFPE). Latorrata et al. [42,112,113] have employed both of these polymers in GDLs and MPLs and compared their behaviors to PTFE and FEP, which are more consolidated alternatives. PFA, like FEP, seems to induce a higher hydrophobic character, while PFPE is correlated to a larger cumulative pore volume of the obtained GDM [41,114-116]. Single fuel cell analyses have revealed that the first two materials perform better in more humid conditions, while the latter in drier atmospheres and higher operating temperatures. Even though both materials perform better than conventional PTFE-treated components, their adoption for fuel cell production has been limited because of the issue of limited adhesion of PFPE-based MPLs, which has not been solved yet. In 
addition, FEP still represents a better alternative, due to its superior performances under all operating conditions (see Table 4 ) and increased durability.

Table 4. Maximum power density values achieved (at $60{ }^{\circ} \mathrm{C}$ and $\mathrm{RH} 80-100 \%$ and $80-60 \%$ ) by fuel cells assembled with GDMs treated with PFPE, FEP, PFA, and PTFE. Data from [117].

\begin{tabular}{ccc}
\hline GDM & \multicolumn{2}{c}{ Maximum Power Density $\mathbf{~} \mathbf{W} \mathbf{~ c m}^{\mathbf{2}}$} \\
\hline & RH $\mathbf{8 0 - 1 0 0 \%}$ & RH 80-60\% \\
\hline PFPE & 447 & 476 \\
FEP & 519 & 481 \\
PFA & 456 & 421 \\
PTFE & 422 & 417 \\
\hline
\end{tabular}

\section{Conclusions}

In this review, a comprehensive description of all the fluorinated materials employed in the gas diffusion medium of PEMFCs has been presented. The focus has been addressed to the several kinds of polymers utilized so far and to their effect on the performance of the device under different operating conditions, mostly in terms of water management, transport of charges and heat, porosity, hydrophobicity, and durability. The correct fluorinated polymer would allow to produce better-performing and more efficient components for fuel cells. However, its choice is not straightforward, as the factors to account for are many and sometimes conflicting: high electrical and thermal conductivities, good adherence and smoothness, extreme durability in chemically and mechanically corrosive environments, and sufficient pore volume while keeping a trade-off between micro- and macro-porosity. A careful optimization of the polymer content is required and must be designed accordingly to the fuel cell operating conditions (temperature and relative humidity).

Currently, the most employed material by the industry is PTFE, whose properties have been largely analyzed. However, many studies have underlined how FEP might represent a better solution, as it grants higher hydrophobicity, prolonged lifetime, and equal conductivities. In addition, it is known that specific applications, such as a $\mathrm{CF}_{4}$ plasma treatment, may be beneficial to the performance of the GDMs. However, it should be considered that simpler techniques, such as dipping or spraying, should be preferred because they reduce production costs, which are still excessive for PEMFCs in comparison to those of traditional energy production systems.

Author Contributions: Conceptualization, S.L., M.M. and M.S.; methodology, S.L., M.M. and A.B.P.; resources, R.B. and G.D.; data curation, M.M. and A.B.P.; writing-original draft preparation, M.M. and A.B.P.; writing-review and editing, S.L., R.B. and M.S.; supervision, S.L.; project administration, G.D.; funding acquisition, G.D. All authors have read and agreed to the published version of the manuscript.

Funding: This research received no external funding.

Institutional Review Board Statement: Not applicable.

Informed Consent Statement: Not applicable.

Data Availability Statement: This work is a review paper summarizing the state of the art and existing data of a specific field. No new data were created in this study.

Conflicts of Interest: The authors declare no conflict of interest.

\section{References}

1. O'Hagan, D. Understanding organofluorine chemistry. An introduction to the C-F bond. Chem. Soc. Rev. 2008, 37, 308-319. [CrossRef] [PubMed]

2. Sudarsan, V. Materials for Hostile Chemical Environments. In Materials Under Extreme Conditions; Elsevier: Amsterdam, The Netherlands, 2017; pp. 129-158. [CrossRef] 
3. Peng, H. Synthesis and Application of Fluorine-Containing Polymers with Low Surface Energy. Polym. Rev. 2019, 59, 739-757. [CrossRef]

4. Wang, Y.; Chen, K.S.; Mishler, J.; Cho, S.C.; Adroher, X.C. A review of polymer electrolyte membrane fuel cells: Technology, applications, and needs on fundamental research. Appl. Ener. 2011, 88, 981-1007. [CrossRef]

5. Wang, Y.; Ruiz Diaz, D.F.; Chen, K.S.; Wang, Z.; Adroher, X.C. Materials, technological status, and fundamentals of PEM fuel cells-A review. Mater. Today 2020, 32, 178-203. [CrossRef]

6. Majlan, E.H.; Rohendi, D.; Daud, W.R.W.; Husaini, T.; Haque, M.A. Electrode for proton exchange membrane fuel cells: A review. Renew. Sustain. Energy Rev. 2018, 89, 117-134. [CrossRef]

7. Jayakumar, A.; Sethu, S.P.; Ramos, M.; Robertson, J.; Al-Jumaily, A. A technical review on gas diffusion, mechanism and medium of PEM fuel cell. Ionics 2015, 21, 1-18. [CrossRef]

8. Omrani, R.; Shabani, B. Gas diffusion layer modifications and treatments for improving the performance of proton exchange membrane fuel cells and electrolysers: A review. Int. J. Hydrogen Energy 2017, 42, 28515-28536. [CrossRef]

9. Ozden, A.; Shahgaldi, S.; Li, X.; Hamdullahpur, F. A review of gas diffusion layers for proton exchange membrane fuel cells-With a focus on characteristics, characterization techniques, materials and designs. Prog. Energy Combust. Sci. 2019, 74, 50-102. [CrossRef]

10. Weber, A.Z.; Newman, J. Effects of Microporous Layers in Polymer Electrolyte Fuel Cells. J. Electrochem. Soc. 2005, 152 , A677. [CrossRef]

11. Gostick, J.T.; Ioannidis, M.A.; Fowler, M.W.; Pritzker, M.D. On the role of the microporous layer in PEMFC operation. Electrohem. Commun. 2009, 11, 576-579. [CrossRef]

12. Park, S.; Lee, J.-W.; Popov, B.N. A review of gas diffusion layer in PEM fuel cells: Materials and designs. Int. J. Hydrogen Energy 2012, 37, 5850-5865. [CrossRef]

13. Kitahara, T.; Nakajima, H.; Ishikawa, K. Gas Diffusion Layer Coated with a Microporous Layer Containing Hydrophilic CNTs to Enhance PEFC Performance without Humidification Using Anode Gas Recirculation. ECS Trans. 2016, 75, 209-217. [CrossRef]

14. Kitahara, T.; Nakajima, H.; Inamoto, M.; Shinto, K. Triple microporous layer coated gas diffusion layer for performance enhancement of polymer electrolyte fuel cells under both low and high humidity conditions. J. Power Source 2014, 248, 1256-1263. [CrossRef]

15. Antonacci, P.; Chevalier, S.; Lee, J.; Ge, N.; Hinebaugh, J.; Yip, R.; Tabuchi, Y.; Kotaka, T.; Bazylak, A. Balancing mass transport resistance and membrane resistance when tailoring microporous layer thickness for polymer electrolyte membrane fuel cells operating at high current densities. Electrochim. Acta 2016, 188, 888-897. [CrossRef]

16. Mariani, M.; Latorrata, S.; Patrignani, S.; Gallo Stampino, P.; Dotelli, G. Characterization of novel graphene-Based microporous layers for Polymer Electrolyte Membrane Fuel Cells operating under low humidity and high temperature. Int. J. Hydrogen Energy 2020, 45, 7046-7058. [CrossRef]

17. Ferreira, R.B.; Falcão, D.S.; Oliveira, V.B.; Pinto, A.M.F.R. Experimental study on the membrane electrode assembly of a proton exchange membrane fuel cell: Effects of microporous layer, membrane thickness and gas diffusion layer hydrophobic treatment. Electrochim. Acta 2017, 224, 337-345. [CrossRef]

18. Ijaodola, O.S.; El-Hassan, Z.; Ogungbemi, E.; Khatib, F.N.; Wilberforce, T.; Thompson, J.; Olabi, A.G. Energy efficiency improvements by investigating the water flooding management on proton exchange membrane fuel cell (PEMFC). Energy 2019, 179, 246-267. [CrossRef]

19. Fan, M.; Duan, F.; Wang, T.; Kang, M.; Zeng, B.; Xu, J.; Anderson, R.; Du, W.; Zhang, L. Effect of Pore Shape and Spacing on Water Droplet Dynamics in Flow Channels of Proton Exchange Membrane Fuel Cells. Energies 2021, 14, 1250. [CrossRef]

20. Mularczyk, A.; Michalski, A.; Striednig, M.; Herrendörfer, R.; Schmidt, T.J.; Büchi, F.N.; Eller, J. Mass Transport Limitations of Water Evaporation in Polymer Electrolyte Fuel Cell Gas Diffusion Layers. Energies 2021, 14, 2967. [CrossRef]

21. Zhou, C.; Guo, L.; Chen, L.; Tian, X.; He, T.; Yang, Q. Pore-Scale Modeling of Air-Water Two Phase Flow and Oxygen Transport in Gas Diffusion Layer of Proton Exchange Membrane Fuel Cell. Energies 2021, 14, 3812. [CrossRef]

22. Park, J.; Oh, H.; Ha, T.; Lee, Y.I.; Min, K. A review of the gas diffusion layer in proton exchange membrane fuel cells: Durability and degradation. Appl. Energy 2015, 155, 866-880. [CrossRef]

23. Lapicque, F.; Belhadj, M.; Bonnet, C.; Pauchet, J.; Thomas, Y. A critical review on gas diffusion micro and macroporous layers degradations for improved membrane fuel cell durability. J. Power Sources 2016, 336, 40-53. [CrossRef]

24. Wong, C.Y.; Wong, W.Y.; Ramya, K.; Khalid, M.; Loh, K.S.; Daud, W.R.W.; Lim, K.L.; Walvekar, R.; Kadhum, A.A.H. Additives in proton exchange membranes for low- and high-temperature fuel cell applications: A review. Int. J. Hydrogen Energy 2019, 44, 6116-6135. [CrossRef]

25. Farooqui, U.R.; Ahmad, A.L.; Hamid, N.A. Graphene oxide: A promising membrane material for fuel cells. Renew. Sustain. Energy Rev. 2018, 82, 714-733. [CrossRef]

26. Shin, D.W.; Guiver, M.D.; Lee, Y.M. Hydrocarbon-Based Polymer Electrolyte Membranes: Importance of Morphology on Ion Transport and Membrane Stability. Chem. Rev. 2017, 117, 4759-4805. [CrossRef] [PubMed]

27. Singh, R.; Oberoi, A.S.; Singh, T. Talwinder Factors influencing the performance of PEM fuel cells: A review on performance parameters, water management, and cooling techniques. Int. J. Energy Res. 2021. [CrossRef]

28. $\mathrm{Hu}, \mathrm{J} . ; \mathrm{Li}, \mathrm{J} . ; \mathrm{Xu}, \mathrm{L} . ;$ Huang, F.; Ouyang, M. Analytical calculation and evaluation of water transport through a proton exchange membrane fuel cell based on a one-Dimensional model. Energy 2016, 111, 869-883. [CrossRef] 
29. Damian-Ascencio, C.E.; Saldaña-Robles, A.; Hernandez-Guerrero, A.; Cano-Andrade, S. Numerical modeling of a proton exchange membrane fuel cell with tree-Like flow field channels based on an entropy generation analysis. Energy 2017, 133, 306-316. [CrossRef]

30. Futter, G.A.; Gazdzicki, P.; Friedrich, K.A.; Latz, A.; Jahnke, T. Physical modeling of polymer-Electrolyte membrane fuel cells: Understanding water management and impedance spectra. J. Power Sources 2018, 391, 148-161. [CrossRef]

31. Zhang, G.; Jiao, K. Multi-phase models for water and thermal management of proton exchange membrane fuel cell: A review. J. Power Sources 2018, 391, 120-133. [CrossRef]

32. Bolwin, K. Preparation of porous electrodes and laminated electrode-Membrane structures for polymer electrolyte fuel cells (PEFC). Solid State Ionics 1995, 77, 324-330. [CrossRef]

33. da Silva, S.L.A.; Ticianelli, E.A. Studies of the limiting polarization behavior of gas diffusion electrodes with different platinum distributions and hydrophobic properties. J. Electroanal. Chem. 1995, 391, 101-109. [CrossRef]

34. Bevers, D.; Rogers, R.; von Bradke, M. Examination of the influence of PTFE coating on the properties of carbon paper in polymer electrolyte fuel cells. J. Power Sources 1996, 63, 193-201. [CrossRef]

35. Paganin, V.A.; Ticianelli, E.A.; Gonzalez, E.R. Development and electrochemical studies of gas diffusion electrodes for polymer electrolyte fuel cells. J. Appl. Electrochem. 1996, 26, 297-304. [CrossRef]

36. Giorgi, L.; Antolini, E.; Pozio, A.; Passalacqua, E. Influence of the PTFE content in the diffusion layer of low-Pt loading electrodes for polymer electrolyte fuel cells. Electrochim. Acta 1998, 43, 3675-3680. [CrossRef]

37. Hočevar, S.; Passalacqua, E.; Vivaldi, M.; Patti, A.; Giordano, N. Electrodics at the gas diffusion platinum electrodes- $\mathrm{H}_{3} \mathrm{PW}_{12} \mathrm{O}_{40}$ proton conducting liquid electrolyte interface. Electrochim. Acta 1996, 41, 2817-2827. [CrossRef]

38. Staiti, P.; Poltarzewsi, Z.; Alderucci, V.; Maggio, G.; Giordano, N. Solid polymer electrolyte fuel cell (SPEFC) research and development at the institute CNR-TAE of messina. Int. J. Hydrogen Energy 1994, 19, 523-527. [CrossRef]

39. Gallo Stampino, P.; Latorrata, S.; Molina, D.; Turri, S.; Levi, M.; Dotelli, G. Investigation of hydrophobic treatments with perfluoropolyether derivatives of gas diffusion layers by electrochemical impedance spectroscopy in PEM-FC. Solid State Ionics 2012, 216, 100-104. [CrossRef]

40. Ong, A.L.; Bottino, A.; Capannelli, G.; Comite, A. Effect of preparative parameters on the characteristic of poly(vinylidene fluoride)-based microporous layer for proton exchange membrane fuel cells. J. Power Sources 2008, 183, 62-68. [CrossRef]

41. Guilizzoni, M.; Santini, M.; Lorenzi, M.; Knisel, V.; Fest-Santini, S. Micro computed tomography and CFD simulation of drop deposition on gas diffusion layers. J. Phys. Conf. Ser. 2014, 547, 012028. [CrossRef]

42. Latorrata, S.; Balzarotti, R.; Gallo Stampino, P.; Cristiani, C.; Dotelli, G.; Guilizzoni, M. Design of properties and performances of innovative gas diffusion media for polymer electrolyte membrane fuel cells. Prog. Org. Coatings 2015, 78, 517-525. [CrossRef]

43. Pai, Y.-H.; Ke, J.-H.; Huang, H.-F.; Lee, C.-M.; Zen, J.-M.; Shieu, F.-S. CF 4 plasma treatment for preparing gas diffusion layers in membrane electrode assemblies. J. Power Sources 2006, 161, 275-281. [CrossRef]

44. Global Fluoropolymers Market 2016-Products, Technologies and Applications. Available online: https://www.globenewswire. com/news-release/2016/06/29/852252/0/en/Global-Fluoropolymers-Market-2016-Products-Technologies-and-Applications. html (accessed on 7 November 2021).

45. Park, G.-G.; Sohn, Y.-J.; Yang, T.-H.; Yoon, Y.-G.; Lee, W.-Y.; Kim, C.-S. Effect of PTFE contents in the gas diffusion media on the performance of PEMFC. J. Power Sources 2004, 131, 182-187. [CrossRef]

46. Niu, Z.; Bao, Z.; Wu, J.; Wang, Y.; Jiao, K. Two-Phase flow in the mixed-Wettability gas diffusion layer of proton exchange membrane fuel cells. Appl. Energy 2018, 232, 443-450. [CrossRef]

47. Kakaee, A.H.; Molaeimanesh, G.R.; Elyasi Garmaroudi, M.H. Impact of PTFE distribution across the GDL on the water droplet removal from a PEM fuel cell electrode containing binder. Int. J. Hydrogen Energy 2018, 43, 15481-15491. [CrossRef]

48. Pan, W.; Chen, Z.; Yao, D.; Chen, X.; Wang, F.; Dai, G. Microstructure and macroscopic rheology of microporous layer nanoinks for PEM fuel cells. Chem. Eng. Sci. 2021, 246, 117001. [CrossRef]

49. Mortazavi, M.; Tajiri, K. Effect of the PTFE content in the gas diffusion layer on water transport in polymer electrolyte fuel cells (PEFCs). J. Power Sources 2014, 245, 236-244. [CrossRef]

50. Puts, G.J.; Crouse, P.; Ameduri, B.M. Polytetrafluoroethylene: Synthesis and Characterization of the Original Extreme Polymer. Chem. Rev. 2019, 119, 1763-1805. [CrossRef]

51. Dai, W.; Wang, H.; Yuan, X.-Z.; Martin, J.; Shen, J.; Pan, M.; Luo, Z. Measurement of water transport rates across the gas diffusion layer in a proton exchange membrane fuel cell, and the influence of polytetrafluoroethylene content and micro-Porous layer. J. Power Sources 2009, 188, 122-126. [CrossRef]

52. Zamel, N.; Li, X.; Becker, J.; Wiegmann, A. Effect of liquid water on transport properties of the gas diffusion layer of polymer electrolyte membrane fuel cells. Int. J. Hydrogen Energy 2011, 36, 5466-5478. [CrossRef]

53. LaManna, J.M.; Kandlikar, S.G. Determination of effective water vapor diffusion coefficient in pemfc gas diffusion layers. Int. J. Hydrogen Energy 2011, 36, 5021-5029. [CrossRef]

54. Flückiger, R.; Freunberger, S.A.; Kramer, D.; Wokaun, A.; Scherer, G.G.; Büchi, F.N. Anisotropic, effective diffusivity of porous gas diffusion layer materials for PEFC. Electrochim. Acta 2008, 54, 551-559. [CrossRef]

55. Hwang, G.S.; Weber, A.Z. Effective-Diffusivity Measurement of Partially-Saturated Fuel-Cell Gas-Diffusion Layers. J. Electrochem. Soc. 2012, 159, F683-F692. [CrossRef] 
56. Biesdorf, J.; Oberholzer, P.; Schmidt, T.J.; Boillat, P. Influence of Hydrophobic Coating of Gas Diffusion Layers on the Performance and Water Transport inside PEFC. ECS Trans. 2014, 64, 467-475. [CrossRef]

57. Biesdorf, J.; Forner-Cuenca, A.; Schmidt, T.J.; Boillat, P. Impact of Hydrophobic Coating on Mass Transport Losses in PEFCs. J. Electrochem. Soc. 2015, 162, F1243-F1252. [CrossRef]

58. Fairweather, J.D.; Cheung, P.; Schwartz, D.T. The effects of wetproofing on the capillary properties of proton exchange membrane fuel cell gas diffusion layers. J. Power Sources 2010, 195, 787-793. [CrossRef]

59. Benziger, J.; Nehlsen, J.; Blackwell, D.; Brennan, T.; Itescu, J. Water flow in the gas diffusion layer of PEM fuel cells. J. Memb. Sci. 2005, 261, 98-106. [CrossRef]

60. Kandlikar, S.G.; Garofalo, M.L.; Lu, Z. Water Management in A PEMFC: Water Transport Mechanism and Material Degradation in Gas Diffusion Layers. Fuel Cells 2011, 11, 814-823. [CrossRef]

61. Ha, T.; Cho, J.; Park, J.; Min, K.; Kim, H.-S.; Lee, E.; Jyoung, J.-Y. Experimental study of the effect of dissolution on the gas diffusion layer in polymer electrolyte membrane fuel cells. Int. J. Hydrogen Energy 2011, 36, 12427-12435. [CrossRef]

62. Burheim, O.S.; Ellila, G.; Fairweather, J.D.; Labouriau, A.; Kjelstrup, S.; Pharoah, J.G. Ageing and thermal conductivity of Porous Transport Layers used for PEM Fuel Cells. J. Power Sources 2013, 221, 356-365. [CrossRef]

63. Yang, P.; Wu, X.; Xie, Z.; Wang, P.; Liu, C.; Huang, Q. Durability improving and corrosion-Resistance mechanism of graphene oxide modified ultra-Thin carbon paper used in PEM fuel cell. Corros. Sci. 2018, 130, 95-102. [CrossRef]

64. Fishman, Z.; Bazylak, A. Heterogeneous Through-Plane Porosity Distributions for Treated PEMFC GDLs I. PTFE Effect. J. Electrochem. Soc. 2011, 158, B841. [CrossRef]

65. Ismail, M.S.; Damjanovic, T.; Ingham, D.B.; Pourkashanian, M.; Westwood, A. Effect of polytetrafluoroethylene-Treatment and microporous layer-Coating on the electrical conductivity of gas diffusion layers used in proton exchange membrane fuel cells. J. Power Sources 2010, 195, 2700-2708. [CrossRef]

66. Ismail, M.S.; Ingham, D.B.; Ma, L.; Pourkashanian, M. The contact resistance between gas diffusion layers and bipolar plates as they are assembled in proton exchange membrane fuel cells. Renew. Energy 2013, 52, 40-45. [CrossRef]

67. El-kharouf, A.; Mason, T.J.; Brett, D.J.L.; Pollet, B.G. Ex-situ characterisation of gas diffusion layers for proton exchange membrane fuel cells. J. Power Sources 2012, 218, 393-404. [CrossRef]

68. Sadeghifar, H. In-Plane and through-Plane electrical conductivities and contact resistances of a Mercedes-Benz catalyst-Coated membrane, gas diffusion and micro-porous layers and a Ballard graphite bipolar plate: Impact of humidity, compressive load and polytetrafluoroe. Energy Convers. Manag. 2017, 154, 191-202. [CrossRef]

69. Zhou, H.; Gao, P.; Wang, P.; Xie, Z.; Wu, X. Titanium nitride (TiN)-Polytetrafluoroethylene (PTFE)-Modified carbon paper used in PEM fuel cells: Characterization and corrosion-Resistant mechanism. Appl. Phys. A 2020, 126, 37. [CrossRef]

70. Burheim, O.S.; Pharoah, J.G. A review of the curious case of heat transport in polymer electrolyte fuel cells and the need for more characterisation. Curr. Opin. Electrochem. 2017, 5, 36-42. [CrossRef]

71. Blumm, J.; Lindemann, A.; Meyer, M.; Strasser, C. Characterization of PTFE Using Advanced Thermal Analysis Techniques. Int. J. Thermophys. 2010, 31, 1919-1927. [CrossRef]

72. Sadeghi, E.; Djilali, N.; Bahrami, M. Effective thermal conductivity and thermal contact resistance of gas diffusion layers in proton exchange membrane fuel cells. Part 2: Hysteresis effect under cyclic compressive load. J. Power Sources 2010, 195, 8104-8109. [CrossRef]

73. Sadeghifar, H.; Djilali, N.; Bahrami, M. Effect of Polytetrafluoroethylene (PTFE) and micro porous layer (MPL) on thermal conductivity of fuel cell gas diffusion layers: Modeling and experiments. J. Power Sources 2014, 248, 632-641. [CrossRef]

74. Sadeghifar, H.; Djilali, N.; Bahrami, M. Counter-Intuitive reduction of thermal contact resistance with porosity: A case study of polymer electrolyte membrane fuel cells. Int. J. Hydrogen Energy 2016, 41, 6833-6841. [CrossRef]

75. Burheim, O.S.; Crymble, G.A.; Bock, R.; Hussain, N.; Pasupathi, S.; du Plessis, A.; le Roux, S.; Seland, F.; Su, H.; Pollet, B.G. Thermal conductivity in the three layered regions of micro porous layer coated porous transport layers for the PEM fuel cell. Int. J. Hydrogen Energy 2015, 40, 16775-16785. [CrossRef]

76. Khandelwal, M.; Mench, M.M. Direct measurement of through-plane thermal conductivity and contact resistance in fuel cell materials. J. Power Sources 2006, 161, 1106-1115. [CrossRef]

77. Zamel, N.; Litovsky, E.; Li, X.; Kleiman, J. Measurement of the through-plane thermal conductivity of carbon paper diffusion media for the temperature range from -50 to $+120^{\circ} \mathrm{C}$. Int. J. Hydrogen Energy 2011, 36, 12618-12625. [CrossRef]

78. Zamel, N.; Litovsky, E.; Shakhshir, S.; Li, X.; Kleiman, J. Measurement of in-plane thermal conductivity of carbon paper diffusion media in the temperature range of $-20^{\circ} \mathrm{C}$ to $+120^{\circ} \mathrm{C}$. Appl. Energy 2011, 88, 3042-3050. [CrossRef]

79. Sadeghi, E.; Djilali, N.; Bahrami, M. A novel approach to determine the in-plane thermal conductivity of gas diffusion layers in proton exchange membrane fuel cells. J. Power Sources 2011, 196, 3565-3571. [CrossRef]

80. Alhazmi, N.; Ismail, M.S.; Ingham, D.B.; Hughes, K.J.; Ma, L.; Pourkashanian, M. The in-Plane thermal conductivity and the contact resistance of the components of the membrane electrode assembly in proton exchange membrane fuel cells. J. Power Sources 2013, 241, 136-145. [CrossRef]

81. Alhazmi, N.; Ingham, D.B.; Ismail, M.S.; Hughes, K.; Ma, L.; Pourkashanian, M. The through-plane thermal conductivity and the contact resistance of the components of the membrane electrode assembly and gas diffusion layer in proton exchange membrane fuel cells. J. Power Sources 2014, 270, 59-67. [CrossRef] 
82. Teertstra, P.; Karimi, G.; Li, X. Measurement of in-plane effective thermal conductivity in PEM fuel cell diffusion media. Electrochim. Acta 2011, 56, 1670-1675. [CrossRef]

83. Ramousse, J.; Didierjean, S.; Lottin, O.; Maillet, D. Estimation of the effective thermal conductivity of carbon felts used as PEMFC Gas Diffusion Layers. Int. J. Therm. Sci. 2008, 47, 1-6. [CrossRef]

84. Karimi, G.; Li, X.; Teertstra, P. Measurement of through-Plane effective thermal conductivity and contact resistance in PEM fuel cell diffusion media. Electrochim. Acta 2010, 55, 1619-1625. [CrossRef]

85. Hamour, M.; Garnier, J.P.; Grandidier, J.C.; Ouibrahim, A.; Martemianov, S. Thermal-Conductivity Characterization of Gas Diffusion Layer in Proton Exchange Membrane Fuel Cells and Electrolyzers Under Mechanical Loading. Int. J. Thermophys. 2011, 32, 1025-1037. [CrossRef]

86. Lee, C.; Mérida, W. Gas diffusion layer durability under steady-State and freezing conditions. J. Power Sources 2007, 164, 141-153. [CrossRef]

87. Cho, J.; Ha, T.; Park, J.; Kim, H.-S.; Min, K.; Lee, E.; Jyoung, J.-Y. Analysis of transient response of a unit proton-Exchange membrane fuel cell with a degraded gas diffusion layer. Int. J. Hydrogen Energy 2011, 36, 6090-6098. [CrossRef]

88. John Felix Kumar, R.; Radhakrishnan, V.; Haridoss, P. Enhanced mechanical and electrochemical durability of multistage PTFE treated gas diffusion layers for proton exchange membrane fuel cells. Int. J. Hydrogen Energy 2012, 37, 10830-10835. [CrossRef]

89. Chen, G.; Zhang, H.; Ma, H.; Zhong, H. Electrochemical durability of gas diffusion layer under simulated proton exchange membrane fuel cell conditions. Int. J. Hydrogen Energy 2009, 34, 8185-8192. [CrossRef]

90. Cho, J.; Park, J.; Oh, H.; Min, K.; Lee, E.; Jyoung, J.-Y. Analysis of the transient response and durability characteristics of a proton exchange membrane fuel cell with different micro-Porous layer penetration thicknesses. Appl. Energy 2013, 111, 300-309. [CrossRef]

91. Zhou, H.; Wang, P.; Gao, P.; Wu, X.; Xie, Z. Enhancement in corrosion resistance and electrical conductivity of hydrophobic-Treated CP by PTFE emulsion containing TiN NPs. Micro Nano Lett. 2019, 14, 1087-1091. [CrossRef]

92. Poornesh, K.K.; Cho, C.D.; Lee, G.B.; Tak, Y.S. Gradation of mechanical properties in gas-Diffusion electrode. Part 2: Heterogeneous carbon fiber and damage evolution in cell layers. J. Power Sources 2010, 195, 2718-2730. [CrossRef]

93. Millichamp, J.; Mason, T.J.; Neville, T.P.; Rajalakshmi, N.; Jervis, R.; Shearing, P.R.; Brett, D.J.L. Mechanisms and effects of mechanical compression and dimensional change in polymer electrolyte fuel cells-A review. J. Power Sources 2015, 284, 305-320. [CrossRef]

94. Destyorini, F.; Indriyati; Indayaningsih, N.; Prihandoko, B.; Syahrial, A.Z. Properties of carbon composite paper derived from coconut coir as a function of polytetrafluoroethylene content. IOP Conf. Ser. Mater. Sci. Eng. 2018, 316, 012054. [CrossRef]

95. Ismail, M.S.; Hassanpour, A.; Ingham, D.B.; Ma, L.; Pourkashanian, M. On the Compressibility of Gas Diffusion Layers in Proton Exchange Membrane Fuel Cells. Fuel Cells 2012, 12, 391-397. [CrossRef]

96. Lim, C.; Wang, C.Y. Effects of hydrophobic polymer content in GDL on power performance of a PEM fuel cell. Electrochim. Acta 2004, 49, 4149-4156. [CrossRef]

97. Song, J.M.; Uchida, H.; Watanabe, M. Effect of Wet-Proofing Treatment of Carbon Backing Layer in Gas Diffusion Electrodes on the PEFC Performance. Electrochemistry 2005, 73, 189-193. [CrossRef]

98. Yan, W.; Hsueh, C.; Soong, C.; Chen, F.; Cheng, C.; Mei, S. Effects of fabrication processes and material parameters of GDL on cell performance of PEM fuel cell. Int. J. Hydrogen Energy 2007, 32, 4452-4458. [CrossRef]

99. Hung, C.-J.; Liu, C.-H.; Ko, T.-H.; Chen, W.-H.; Cheng, S.-H.; Chen, W.-S.; Yu, A.; Kannan, A.M. Effect of diffusion layers fabricated with different fiber diameters on the performance of low temperature proton exchange membrane fuel cells. J. Power Sources 2013, 221, 134-140. [CrossRef]

100. Park, S.B.; Park, Y. Fabrication of gas diffusion layer (GDL) containing microporous layer using flourinated ethylene prophylene (FEP) for proton exchange membrane fuel cell (PEMFC). Int. J. Precis. Eng. Manuf. 2012, 13, 1145-1151. [CrossRef]

101. Öztürk, A.; Fıçıcılar, B.; Eroğlu, İ.; Bayrakçeken Yurtcan, A. Facilitation of water management in low Pt loaded PEM fuel cell by creating hydrophobic microporous layer with PTFE, FEP and PDMS polymers: Effect of polymer and carbon amounts. Int. J. Hydrogen Energy 2017, 42, 21226-21249. [CrossRef]

102. Hasanpour, S.; Ahadi, M.; Bahrami, M.; Djilali, N.; Akbari, M. Woven gas diffusion layers for polymer electrolyte membrane fuel cells: Liquid water transport and conductivity trade-Offs. J. Power Sources 2018, 403, 192-198. [CrossRef]

103. Latorrata, S.; Gallo Stampino, P.; Cristiani, C.; Dotelli, G. Development of an optimal gas diffusion medium for polymer electrolyte membrane fuel cells and assessment of its degradation mechanisms. Int. J. Hydrogen Energy 2015, 40, 14596-14608. [CrossRef]

104. Latorrata, S.; Cristiani, C.; Dotelli, G. Performance Evaluation and Durability Enhancement of FEP-Based Gas Diffusion Media for PEM Fuel Cells. Energies 2017, 10, 2063. [CrossRef]

105. Chevalier, S.; Lavielle, N.; Hatton, B.D.; Bazylak, A. Novel electrospun gas diffusion layers for polymer electrolyte membrane fuel cells: Part I. Fabrication, morphological characterization, and in situ performance. J. Power Sources 2017, 352, 272-280. [CrossRef]

106. Bottino, A.; Capannelli, G.; Comite, A.; Costa, C.; Ong, A.L. Microporous layers based on poly(vinylidene fluoride) and sulfonated poly(vinylidene fluoride). Int. J. Hydrogen Energy 2015, 40, 14690-14698. [CrossRef]

107. Li, T.; Lei, Y.; Gu, J.; Yu, T.; Liu, J.; Zou, Z. Application of ployvinylidene fluoride-Hexafluoroprorylene in gas diffusion layer of proton exchange membrane fuel cell. Procedia Eng. 2012, 27, 526-530. [CrossRef] 
108. Su, H.; Jao, T.-C.; Pasupathi, S.; Bladergroen, B.J.; Linkov, V.; Pollet, B.G. A novel dual catalyst layer structured gas diffusion electrode for enhanced performance of high temperature proton exchange membrane fuel cell. J. Power Sources 2014, $246,63-67$. [CrossRef]

109. Su, H.; Pasupathi, S.; Bladergroen, B.; Linkov, V.; Pollet, B.G. Optimization of gas diffusion electrode for polybenzimidazole-Based high temperature proton exchange membrane fuel cell: Evaluation of polymer binders in catalyst layer. Int. J. Hydrogen Energy 2013, 38, 11370-11378. [CrossRef]

110. Kang, R.-J.; Chen, Y.-S. Experimental Study on the Effect of Hydrogen Sulfide on High-Temperature Proton Exchange Membrane Fuel Cells by Using Electrochemical Impedance Spectroscopy. Catalysts 2018, 8, 441. [CrossRef]

111. Lin, H.-L.; Wu, T.-J.; Lin, Y.-T.; Wu, H.-C. Effect of polyvinylidene difluoride in the catalyst layer on high-Temperature PEMFCs. Int. J. Hydrogen Energy 2015, 40, 9400-9409. [CrossRef]

112. Balzarotti, R.; Latorrata, S.; Stampino, P.G.; Cristiani, C.; Dotelli, G. Development and Characterization of Non-Conventional Micro-Porous Layers for PEM Fuel Cells. Energies 2015, 8, 7070-7083. [CrossRef]

113. Latorrata, S.; Sansotera, M.; Gola, M.; Stampino, P.G.; Navarrini, W.; Dotelli, G. Innovative Perfluoropolyether-Functionalized Gas Diffusion Layers with Enhanced Performance in Polymer Electrolyte Membrane Fuel Cells. Fuel Cells 2020, 20 , 166-175. [CrossRef]

114. Balzarotti, R.; Latorrata, S.; Mariani, M.; Gallo Stampino, P.; Dotelli, G. Optimization of Perfluoropolyether-Based Gas Diffusion Media Preparation for PEM Fuel Cells. Energies 2020, 13, 1831. [CrossRef]

115. Gola, M.; Sansotera, M.; Navarrini, W.; Bianchi, C.L.; Gallo Stampino, P.; Latorrata, S.; Dotelli, G. PerfluoropolyetherFunctionalized gas diffusion layers for proton exchange membrane fuel cells. J. Power Sources 2014, 258, 351-355. [CrossRef]

116. Sansotera, M.; Navarrini, W.; Gola, M.; Dotelli, G.; Stampino, P.G.; Bianchi, C.L. Conductivity and superhydrophobic effect on PFPE-modified porous carbonaceous materials. Int. J. Hydrogen Energy 2012, 37, 6277-6284. [CrossRef]

117. Latorrata, S.; Gallo Stampino, P.; Cristiani, C.; Dotelli, G. Novel superhydrophobic microporous layers for enhanced performance and efficient water management in PEM fuel cells. Int. J. Hydrogen Energy 2014, 39, 5350-5357. [CrossRef] 